\title{
Javanese Language Maintenance at Dieng's Dreadlock Hair Cutting Tradition to Support Banjarnegara Local Tourism
}

\author{
Wiwiek Sundari ${ }^{1}$ \\ ${ }^{1}$ English Literature Study Program, Linguistics Department, Faculty of Humanities, Diponegoro \\ University, Semarang, Indonesia
}

\begin{abstract}
Language is human creation representing a complex system of thought and practice. It can be history when the speakers stop using it and pass it into the next generation. To maintain it, speakers should keep using it as their cultural identity and part of their civilization. Tradition makes language continuously used throughout time. This research shows how the Javanese language is maintained through a tradition of cutting natural dreadlock hair of particular kids in Dieng to support local tourism, which is done by using folklore field research to get the data. The research shows that the local people use old and modern Javanese language in the ceremony as part of the language and culture maintenance.
\end{abstract}

\section{Research Background}

The The word culture derives from the Latin word 'cultural, referring to cult or worship. Culture itself is defined as human beings creation representing their way of thinking and life that can be self-created, inherited from their ancestors, passed to their descendants, or learnt from other societies. Javanese language as part of Javanese culture, which is created by, inherited from, and passed to Javanese people, should be maintained by the Javanese ethnic and Indonesian people as the owner of the culture. It is done by using and passing it into the next generation. Javanese and Indonesian people should be alert that globalization might threaten their culture by switching, shifting and replacing the old and traditional with the new and modern one that makes the culture becomes history, exposed to their descendants in manuscript and museum.

The rise of modern popular culture adorned by the new generation may gradually substitute their culture as it is unpopular. The threat to Javanese culture happened when the number of Javanese people maintaining Javanese culture declined due to the negative attitude toward their own culture. Only particular Javanese young generation speak the Javanese language, wear Javanese clothing, consume Javanese food and beverage, follow Javanese tradition, or think and live like their ancestors. This research shows how Dieng people in Banjarnegara maintain Javanese culture and language by keeping the tradition of cutting the natural dreadlock hair of particular kids in Dieng. 


\section{Theoretical Background}

Javanese culture reflects Javanese people's principles of life, making them live the way they live from the past until the present. It should be able to be used in the future as their cultural identity in their civilization. Javanese language as part of Javanese culture was previously used as the primary communication tool among Javanese people in three levels of language politeness of Ngoko, Madya, Krama, Krama Inggil. Nowadays, only certain Javanese people understand and speak the whole politeness level. The youngest generation only understandsunderstands and speaks the Ngoko one, even when speaking with older people.

Since Javanese culture and language can be shifted, substituted, extinct or even dead, the problem should be solved. The declining number of its speakers shows a common language threat due to different reasons. It is considered less popular, less beneficial, or less profitable than other languages. As a result, only a limited number of Javanese people, particularly the young generation, understand and speak the Javanese language and its three language politeness levels. Javanese language may only be used and maintained by Javanese minorities in particular numbers and areas. Javanese people may also change their attitude toward their own language as a result of the political, economic and social changes reducing culture and language value, usage and respect [1].

Let's look at what Pauwels [2] had thoroughly explained about language maintenance and shift. The threat on the Javanese language is mild since the diglossic or multilingual situations is not present. There are Javanese communities who continue using their local language as their mother tongue in their daily activities, and the second language like Bahasa Indonesia or the foreign language like English is only used in particular situations such as at school to talk with teachers or in an international forum to talk with foreigners.

However, the situation might change due to globalization, where information can be accessed in any language. People worldwide can be connected by technology using a national language like Bahasa Indonesia and a global language like English. Moreover, when it comes to the social psychology of the minorities, like the Javanese language as an indigenous language, the inferior might feel reluctant to show their cultural identity like the local language and choose to use the more beneficial and 'high' language [2].

The local government of Dieng, Banjarnegara, support the old and modern Javanese language usage in the traditional ceremony of cutting the natural dreadlock of particular kids in the area. In the ceremony, the respected older people use the old Javanese language in their mantra and prayer. In contrast, the kids and the visitors use modern Javanese language with three different levels of language politeness. The participants were also requested to wear traditional Javanese clothing, and they were given traditional Javanese food as an offering to God to express their gratitude.

\section{Research Methodology}

During pandemic Covid-19, this research is done in two virtual steps. Virtual field research is done by documenting the tradition in which the researcher took 2 (two) research objects, old and modern Javanese languages, using the Purposive Sampling Technique [3] to show the Javanese language that Javanese people still use. The researcher also took 4 (four) research subjects, that are 2 (two) kids and 2 (two) adults, who were using modern Javanese language using the Purposive Sampling Technique [3] to see how they speak the language. To get a broad conclusion, the researcher digs more information from informants by giving virtual Questionnaires and holding virtual Interviews [4] to see their Javanese culture and language background. The data were analysed using 7 (seven) cultural universalities of 
language [5] and Culture and Language Maintenance Theory [1, 6, 7] to know (1) how Dieng people maintain the Javanese language and (2) the reason why they maintain it.it.

\section{Finding and Discussion}

\subsection{Finding}

From the virtual field research, the researcher found 2 (two) kinds of Javanese language used in the traditional ceremony of cutting the natural dreadlock hair of certain kids in Dieng, Banjarnegara. The old Javanese language is used in traditional songs containing mantras spelt by an old and respected Javanese religious leader who cut the kids' hair and prayer sung by a particular singer appointed by him. Meanwhile, the kids, the kids' parents, and the local government officials use the modern Javanese language as follows.

\section{Kidung Rumeksa ing Wengi}

Ana kidung rumeksa ing wengi, Teguh hayu luputa ing Lara

Luputa bilahi kabeh, Jim setan datan purun

Paneluhan tan ana wani, Miwah panggawe ala

Gunaning wong luput, Geni atemahan tirta

Maling adoh tan ana ngarah ing mami, Guna duduk pan sirna

Sakehing lara pan samya bali, Sakeh ngama pan sami miruda

Welas asih pandulune, Sakehing braja luput

Kadi kapuk tibaning wesi, Sakehing wisa tawa

Sato galak tutut, Kayu aeng lemah sangar

Songing landhak guwaning wong lemah miring, Myang pakiponing merak

Pagupakaning warak sakalir, Nadyan arca myang segara asat

Temahan rahayu kabeh, Apan sarira ayu

Ingideran kang widadari, Rineksa malaekat

Sakathahing Rasul, Pan dadi sarira Tunggal

Ati Adam Utekku Baginda Esis, Pangucapku ya Musa

Napasku Nabi Ngisa linuwih, Nabi Yakup Pamiyar saningwang

Yusup ing rupaku mangke, Nabi Dawud Suwaraku

Jeng Suleman kasekten mami, Nabi Ibrahim nyawaku

Edris ing Rambutku, Baginda Ngali kulitingwang

Getih daging Abubakar singgih, Balung Baginda Ngusman

Sungsumingsun Patimah linuwih, Siti Aminah Bayuning Angga

Ayup ing Ususku mangke, Nabi Nuh ing Jejantung

Nabi Yunus ing Otot mami, Netraku ya Muhammad

Pamuluku Rasul, Pinayungan Adam sarak

Sampun pepak sakatahe para, Nabi dadya sarira Tunggal

Wiji sawiji mulane dadi, Apan apencar dadiya sining jagad

Kasamadan dening Dzate, Kang maca kang angrungu

Kang anurat kang anyimpeni, Dadi ayuning badan

Kinarya sesembur, Yen winacakna toya 


\begin{tabular}{|c|}
\hline Kinarya dus rara gelis laki, Wong edan dadi waras \\
Lamun ana wong kadhendha kaki, Wong kabanda wong kabotan utang \\
Yogya wacanen den age, Nalika tengah dalu \\
Ping sawelas macanen singgih, Luwar saking kabanda \\
Kang kadhendha wurung, Aglis nuli sinauran mring hyang \\
Suksma kang utang puniku singgih, Kang agring nuli waras \\
Lamun arsa tulus nandur pari, Puwasaa sawengi sadina \\
Iderana gelengane, Wacanen kidung iku \\
Sakeh ngama sami abali, Yen sira lunga perang \\
Wateken ing sekul, Antuka tigang pulukan \\
Musuhira rep sirep tan ana wani, Rahayu ing payudan \\
Sing sapa reke bisa nglakoni, Amutiya lawan anawaa \\
Patang puluh dina wae, Lan tangi wektu subuh \\
Lan den sabar sukuring ati, Insya Allah tinekan \\
Sakarsanireku, Tumrap sanak rakyatira \\
Saking sawabing ngelmu pangiket mami, Duk aneng Kalijaga \\
\hline
\end{tabular}

Fig. 1. A traditional song called Kidung Rumeksa ing Wengi [8].

The The traditional song in Figure 1 above is written in an old Javanese language that Javanese people no longer use in daily communication. The song contains a mantra used by an old and respected Javanese religious leader and prayer sung by a particular singer appointed by him to perform the special duty since it cannot be performed by commoners. The song was also performed during the ceremony for the sake of the kids' safety.

Meanwhile, the following dialogues show the use of a modern Javanese language between the kids and the kids' parents and between the kids and the local government officer using Ngoko and Madya politeness level. Some announcements were spoken using Krama Inggil politeness level. It shows the use of the language in three levels of politeness as follows.

\section{Announcements}

1. Para rawuh sekedhap malih jamasan bade kalaksanan.

2. Mugi putro ingkang badhe kaparas utawi sampun kaparas keparingan sehat jasmani rohani, wilujeng, tansah mangih karahayon.

3. Pramilo saking mekaten, acara saklajengipun, njih menika wilujengan.

Fig. 2. Announcements using modern Javanese language in Krama.

During the ceremony, a person in charge who was performing as a master of ceremony was announcing several announcements to the visitors using modern Javanese language in Krama Inggil politeness. On the next dialogues, the participants use Ngoko and Madya politeness level. 


\section{Dialogues}

Dialogue 1 (Ngoko)

Father : Rambut gimbalmu dipotong ya?

Kid : Aku njaluk hadiah.

Father: Hadiah apa?

Kid : Kalung emas.

Dialogue 2 (Madya)

Head of Dieng District : Arep hadiah apa rambutmu dicukur?

Kid : Tivi.

Head of Dieng District : Tivi gede apa cilik?

Kid : Gede.

Head of Dieng District : Ya mengko nyuwun bapakmu, yo ?

Fig. 3. Dialogues reflecting modern Javanese language use in Ngoko and Madya.

Before the ceremony, the parents or the head of Dieng district as representative of the Dieng government officer ask the kids with natural dreadlock hair that will be cut by an old and respected Javanese religious leader about a gift they wanted for their willingness to cut the hair. In this tradition, the kids have a special privilege to ask any gift as a substitute of cutting their hair. On the first dialogue, both father and kid use modern Javanese language with Ngoko politeness level. On the second dialogue, the officer uses Madya politeness level to teach the kid how to speak politely with an older people like him.

\subsection{Discussion}

\subsubsection{Dieng, Banjarnegara and Wonosobo, Central Java}

Dieng Plateau lies on 6.802 feet height or $2.093 \mathrm{~m}$ dpl with a geographical position on 7' 12' North Latitude and 109' 54' East Longitude. It is divided into two administrative areas of West Dieng in Banjarnegara District and East Dieng in Wonosobo District, Central Java. The plateau is known for its cold temperature of $15^{\circ} \mathrm{C}$ on normal days and dropping to $0^{\circ} \mathrm{C}$ on cold days in July and August. The hail and frosty plants on the ground becomes one of many tourism attractions beside Dieng famous archaeological sites like temples and craters with its geyser. There is also a great cultural phenomenon of natural dreadlock hair of particular kids that must be specially cut in a traditional ceremony served as a cultural tourism attraction [8]. 


\subsubsection{Kids with Natural Dreadlock Hair}

Particular kids in Dieng grow natural dreadlock hair called gimbal or gembel. Local people believe that those kids were the descendants of Kyai Kolodete, the ancestor of Dieng Plateau who lived during the glory of Matarang Kingdom. He was the first person who opened the plateau and made it into a new place to dwell with his followers, which was then developed into an administrative area in Central Java. He is known for his natural dreadlock hair. That is why Dieng local people believe that the kids with natural dreadlock hair were the descendants of Kyai Kolodete.

The local people believe that kids with dreadlock hair are special as not all Dieng kids grow that hair. The dreadlock hair is naturally growing on kids below 5 (five) years old after a high fever and a delirious. There is no medication to cure the kids as they will be recovering by themselves, leaving tangled hair due to the heavy sweat during the high fever. The hair cannot be unravelled even though it has been washed with various kinds of soap or shampoo. When the hair is cut, the new hair will naturally grow like dreadlock hair which is denser and tangler.

To completely remove the dreadlock hair, local people must hold a traditional ceremony called ruwatan or ngruwat with particular requirements. For this ritual, the kids were treated like a king and a queen who could ask for any gift as a reward for their willingness to cut (or remove) the dreadlock hair. Otherwise, the dreadlock hair will continuously grow or grow back after being cut without any ritual.

\subsubsection{Ngruwat Traditional Ceremony}

The Ngruwat traditional ceremony is annually held in Arjuna Temple areas by Dieng and Banjarnegara residents supported by the local government as cultural and traditional tourism called Dieng Culture Festival [10]. This ritual is aimed at removing particular Dieng's kids' dreadlock hair, to get rid of their bad luck, to ask for God's mercy and blessing for the kids and the whole Dieng people, as well as to attract local, regional, and international tourists to enjoy this annual tourism event. The tourists are interested in coming since they are curious about how the kids naturally got the hair and how it must be removed in a particular ritual.

Before cutting the dreadlock hair, the old and respected Javanese religious leader starts the traditional ceremony with a particular prayer using a mantra in the old Javanese language. Meanwhile, the master of ceremony opens the ceremony using modern Javanese language in Krama Inggil politeness level. The following example shows opening, information, and requests to bless the kid who will run the tradition.

"Sederek sedaya, kula atas naminipun ingkang gadah hajad, dalu punika sederek sedaya dipun aturi lenggahan wonten ngriki. Dahar eca boten, sarehne Naja (the kid's name) bade anetakaken gembelipun, para sederek sedaya kula aturi maringi idi pangestu lan wilujeng. " [9]

During During the ceremony, the master always speaks and gives announcements for the visitors in modern Javanese language with Krama Inggil politeness level (see Fig. 2), although not all visitors understand the language. Krama Inggil is used to honour the visitors as a guest who must be honoured by the host as one of the Javanese basic principles of life, although not all guests are older than the master of ceremony.

After opening the ceremony with a mantra and prayer in a particular song (See Fig. 1), the old and respected Javanese religious leader starts to cut the kids dreadlock hair. Before the haircut begins, he asks the kids' parents and requests the head of Dieng District as the 
representative of the local government to ask the kids about the gift they want for cutting their dreadlock hair. This requested gift is an important request that must be granted if the dreadlock hair wants to be removed entirely. Otherwise, the dreadlock hair will continuously grow, and the kids' safety may be threatened. The whole ritual was explained by the master of ceremony in modern Javanese language with Krama Inggil politeness level.

In their daily conversation, Dieng local people usually use modern Javanese language in Ngoko politeness level except for adult or senior citizens who are able to use Madya and Krama politeness level. That is why in Fig.3, a father and a kid is communicating using Ngoko as the kid usually talks with his parents using that politeness level. When an older person like the head of Dieng District tries to teach a kid to use Madya by talking to him using that politeness level, he still replies in Ngoko as he is not accustomed to using Madya or Krama to talk to an older person, even with a stranger.

Besides showing the use of old and modern Javanese language, this traditional ceremony also exposes the Javanese traditional clothing and cuisine to the visitors, reflecting Javanese culture maintenance by Dieng local people, which is fully supported by Banjarnegara local government. Unlike Sundari's research on Javanese language and culture maintenance in Dhoplang, Wonogiri, Central Java [10], where visitors were requested to use Javanese language and wear traditional Javanese clothing, in this research, the researcher found out that visitors were only offered to wear traditional Javanese clothing called lurik and traditional Javanese hat called caping as well as to taste the traditional Javanese cuisine from the offerings to experience being Javanese. These clothing and cuisine were also sold as souvenirs for visitors to empower the local people to get more income.

\section{Conclusion}

From the data analysis on the finding and discussion, the researcher found out that both the Dieng local people and Banjarnegara local government had already made their best effort to maintain Javanese language and culture by preserving the traditional ceremony of cutting Dieng's kids' natural dreadlock hair which the local people believe to be beneficial for the kids' safety, the local people business, and the local government tourism promotion.

The whole effort shows that if the language speakers as the culture owners keep their language use, both the language and the culture will not be easily shifted, replaced, endangered, extinct or dead. In fact, it will be maintained and also learnt by people around the world. This way, the language becomes the national wealth that can be spread throughout the world so that the owner of the language can be proud of their indigenous language as their cultural identity.

\section{References}

1. J. Holmes, An Introduction to Sociolinguistics, (Longman New York, 1992)

2. A. Pauwels, Language Maintenance and Shift, (Cambridge University Press Cambridge, 2016)

3. Sugiyono, Metode Penelitian Kualitatif dan R\&D, (CV Alfabeta Bandung, 2010)

4. Sudaryanto, Metode dan Aneka Teknik Analisis Bahasa, (Pengantar Penelitian Wacana Kebudayaan secara Linguistik), (Duta Wacana Yogyakarta, 1993)

5. Koentjaraningrat, Pengantar Ilmu Antropologi, (Rineka Cipta Jakarta, 2000)

6. R. Fasold, Sociolinguistics of Language, (Blackwell Oxford, 1994)

7. R. Wardaugh, An Introduction to Sociolinguistics, (Massachusetts Cambridge, 1995) 
8. S. A. Nugroho, Upacara Ngruwat Gimbal di Desa Dieng Kulon Kecamatan Batur Kabupaten Banjarnegara. Final Paper, (UNY Yogyakarta, 2014)

9. Y. Febrianda, (2015), Mitos Anak Gembel Pada Masyarakat Dataran Tinggi Dieng, Retrieved from http://catatansikudaliar.blogspot.com/2015/10/mitos-anak-gembel-padamasyarakat.html

10. W. Sundari, Javanese Culture Maintenance at Dhoplang Traditional Culinary Market, Wonogiri, to Support Plasticless Society, Article on $5^{\text {th }}$ ICENIS International Proceeding Semarang August, $12^{\text {th }}-13^{\text {th }},(2020)$ 